\title{
RECURRING CRISES IN ANGLO-AMERICAN CORPORATE GOVERNANCE
}

\section{Thomas Clarke}

Contributions to Political Economy, Oxford University Press, 2010, 29, 1, pp. 9-32.

\begin{abstract}
The prolonged systemic crisis in international financial markets commencing in 2007 was also a crisis in corporate governance and regulation. The apparent ascendancy of Anglo-American markets and governance institutions was profoundly questioned by the scale and contagion of the global financial crisis. Instead of risk being hedged, it had become inter-connected and international, and unknown. The market capitalisation of the stock markets of the world had peaked at $\$ 62$ trillion at the end of 2007, but were by October 2008 in free fall, having lost $\$ 33$ trillion dollars, over half of their value in12 months of unrelenting financial and corporate failures. A debate has continued for some time about the costs and benefits of the financialisation of advanced industrial economies. The long progression of financial crises around the world served as a reminder that the system is neither self-regulating or robust. The explanation of why investment banks and other financial institutions took such spectacular risks with extremely leveraged positions on many securities and derivatives, and the risk management, governance and ethical environment that allowed such conduct to take place is demands detailed analysis.
\end{abstract}

\section{Recurring Crises In Anglo-American Corporate Governance}




\section{Thomas Clarke}

The prolonged systemic crisis in international financial markets commencing in 2007/ 2008 was also a crisis in corporate governance and regulation. The most severe financial disaster since the Great Depression of the 1930s exposed the dangers of unregulated financial markets and nominal corporate governance. The crisis originated in Wall Street where de-regulation unleashed highly incentivised investment banks to flood world markets with toxic financial products. As a stunning series of banks and investment companies collapsed in the United States and then in Europe, a frightening dimension of the global economy became fully apparent: a new world disorder of violently volatile markets and deep financial insecurity. Advocating systemic change President Nicolas Sarkozy of France proclaimed, “The world came within a whisker of catastrophe. We can’t run the risk of it happening again. Self-regulation as a way of solving all problems is finished. Laissez-faire is finished. The all-powerful market that always knows best is finished” (Washington Post 28 September 2008), as if presidential rhetoric alone could sweep away an enveloping, financially driven political economy. For decades Europe has actively sought deeper financial integration with the United States, reducing barriers to trade, and liberalizing markets, leading onwards towards globalisation. Transatlantic integration is forging economic relations involving financial markets, services, manufacturing, pharmaceuticals, telecommunications and other industry sectors (CTR/CEPS 2005). However, for this effort at integrating markets and businesses to succeed, a supporting integration of institutions, regulation and corporate governance is required. European legal institutions, regulatory, governance and accounting practices face insistent pressures to adapt to the reality of international competitive markets. The European relationship-based corporate governance systems in particular are often criticised as being inherently less efficient than the Anglo-American market based systems.

\section{IMPLICATIONS OF THE 2008 WALL STREET FINANCIAL CRISIS}


“America's financial institutions have not managed risk;

they have created it” (Joseph Stiglitz 2008a).

Figure 1 Collapsing Stock Exchanges in 2008 Global Financial Crisis

(Year to 2 December 2008)

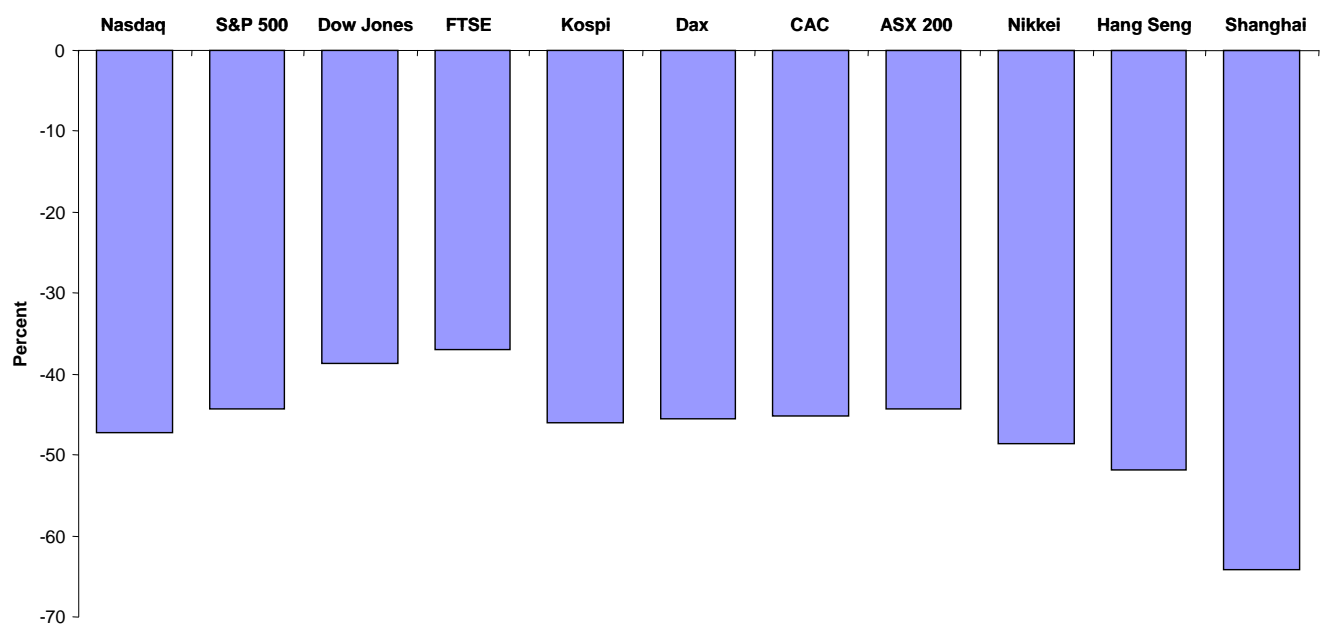

Sources: Stock Exchanges

The apparent ascendancy of Anglo-American markets and governance institutions was profoundly questioned by the scale and contagion of the 2008 global financial crisis. The crisis was initiated by falling house prices and rising mortgage default rates in the highly inflated US housing market. A severe credit crisis developed through 2007 into 2008 as financial institutions became fearful of the potential scale of the sub-prime mortgages concealed in the securities they had bought. As a result banks refused to lend to each other because of increased counter-party risk that other banks might default. A solvency crisis ensued as banks were slow to admit to the great holes in their accounts the sub-prime mortgages had caused (partly because they were themselves unaware of the seriousness of the problem), and the difficulty in raising capital to restore their balance sheets. As an increasing number of financial institutions collapsed in the US, UK, and Europe, successive government efforts to rescue individual institutions, and to offer general support for the financial system, did not succeed in restoring confidence as markets continued in free-fall, with stock exchanges across the world losing half their value (Figure 1). 
Financial insecurity rapidly became contagious internationally as fears of a global economic recession became widespread and stock markets around the world crashed. This financial crisis was larger in scale than any crisis since the 1930s Great Depression, involving losses conservatively estimated in October 2008 by the IMF (2008) as potentially $\$ 1,400$ billion dollars, eclipsing earlier crises in Asia, Japan and the US (Figure 2). Martin Wolf was quick to realise the implications of the crisis, as he put it in the Financial Times (5 September 2007) "We are living through the first crisis of the brave new world of securitised financial markets. It is too early to tell how economically important the upheaval will prove. But nobody can doubt its significance for the financial system. Its origins lie with credit expansion and financial innovations in the US itself. It cannot be blamed on 'crony capitalism’ in peripheral economies, but rather on responsibility in the core of the world economy."

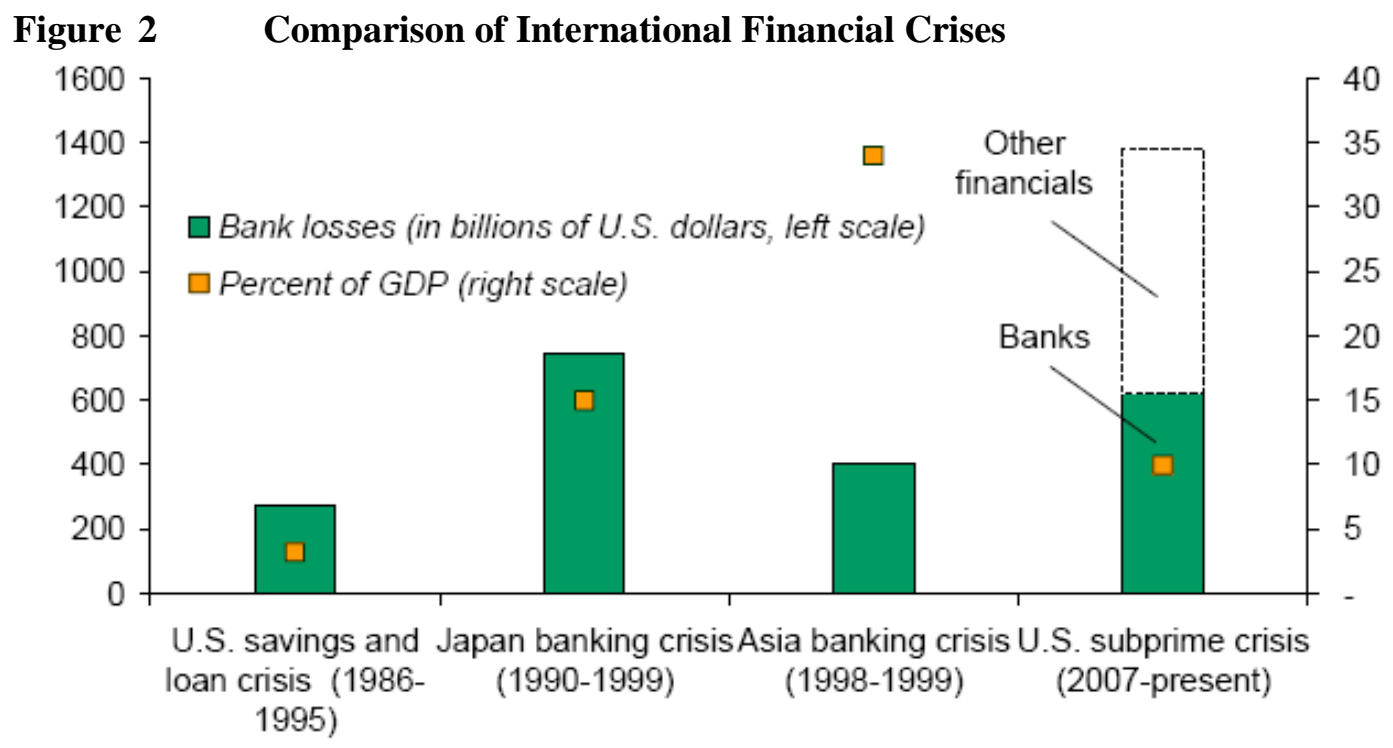

Sources: World Bank; and IMF staff estimates.

Note: U.S. subprime costs represent staff estimates of losses on banks and other financial institutions from Table 1.1. All costs are in real 2007 dollars. Asia includes Indonesia, Malaysia, Korea, the Philippines, and Thailand.

Source: IMF (2008a:9)

\section{Origins of the Crisis}

In the cyclical way markets work, the origins of the 2008 financial crisis may be found in the solutions to the previous market crisis. The US Federal Reserve under the sage Alan Greenspan 
responded to the collapse of confidence caused by the dot-com disaster and Enron failures in 2001/2002 by reducing US interest rates to one per cent, their lowest in 45 years, flooding the market with cheap credit to jump-start the economy back into life. US business did recover faster than expected, but the cheap credit had washed into the financial services and housing sectors producing the largest speculative bubbles ever witnessed in the American economy (Fleckenstein 2008). The scene was set by the 1999 dismantling of the 1932 Glass-Steagall Act which had separated commercial banking from investment banking and insurance services, opening the way for a consolidation of the vastly expanding and increasingly competitive US financial services industry. Phillips (2008:5) describes this as a "burgeoning debt and credit complex": "Vendors of credit cards, issuers of mortgages and bonds, architects of asset-backed securities and structured investment vehicles - occupied the leading edge. The behemoth financial conglomerates, Citigroup, JP Morgan Chase et al, were liberated in 1999 for the first time since the 1930s to marshal banking, insurance, securities, and real estate under a single, vaulting institutional roof.” In this newly emboldened finance sector the name of the game was leverage - the capacity to access vast amounts of credit cheaply to takeover businesses and to do deals. Wall Street investment banks and hedge funds flourished with their new found access to cheap credit. Exotic financial instruments were devised and marketed internationally: futures, options and swaps evolved into collateralized debt obligations (CDOs), credit default swaps (CDSs), and many other acronyms, all of which packaged vast amounts of debt to be traded on the securities markets. Abandoning their traditional financial conservatism banks looked beyond taking deposits and lending to the new businesses of wealth management, and eagerly adopted new instruments and business models. As the IMF put it "Banking systems in the major countries have gone through a process of disintermediation — that is, a greater share of financial intermediation is now taking place through tradable securities (rather than bank loans and deposits)...Banks have increasingly moved financial risks (especially credit risks) off their balance sheets and into securities 
markets—for example, by pooling and converting assets into tradable securities and entering into interest rate swaps and other derivatives transactions—in response both to regulatory incentives such as capital requirements and to internal incentives to improve risk-adjusted returns on capital for shareholders and to be more competitive... Securitization makes the pricing and allocation of capital more efficient because changes in financial risks are reflected much more quickly in asset prices and flows than on bank balance sheets. The downside is that markets have become more volatile, and this volatility could pose a threat to financial stability” (2002:3).

\section{Global Derivatives Markets}

As the new financial instruments were developed and marketed, the securities markets grew massively in the 2000s dwarfing the growth of the real economy. For example, according to the Bank of International Settlements the global derivatives markets grew at the rate of 32\% per annum from 1990, and the notional amount of derivatives reached 106 trillion dollars by 2002, 477 trillion dollars by 2006, and exceeded 531 trillion dollars by 2008 (though gross market value is a small fraction of this) (McKinsey 2008:20). The supposed purpose of this increasingly massive exercise was to hedge risk and add liquidity to the financial system. Derivatives allow financial institutions and corporations to take greater and more complex risks such as issuing more mortgages and corporate debt, because they may protect debt holders against losses. Since derivatives contracts are widely traded, risk may be further limited, though this increases the number of parties exposed if defaults occur. "Complex derivatives were at the heart of the credit market turmoil that rippled through financial markets in 2007, raising concerns about the financial players' abilities to manage risk as capital markets rapidly evolve. Unlike equities, debt securities and bank deposits, which represent financial claims against future earnings by households and companies, derivatives are risk-shifting agreements among financial market participants” (McKinsey 2008:20). Because of this fundamental difference and indeterminacy McKinsey did not include derivatives in their calculation of the value of global 
financial assets, an indication of the ephemeral quality of derivatives. Yet derivatives certainly have their defenders who claim they make an essential contribution to international liquidity. A riveting analysis of the legacy of the former Chairman of the Federal Reserve in the New York Times, detailed how Alan Greenspan defended derivatives markets as an innovation helping to develop and stabilise the international financial system, "Not only have individual financial institutions become less vulnerable to shocks from underlying risk factors, but also the financial system as a whole has become more resilient.” Others were less sanguine, and both George Soros and Warren Buffett avoided investing in derivatives contracts because of their impenetrable complexity. Buffet described derivatives in 2003 as "financial weapons of mass destruction, carrying dangers that, while now latent, are potentially lethal,” and pointed out that collateralised debt obligation contracts could stretch to 750,000 pages of impenetrable (and presumably unread) text (New York Times 8 October 2008).

Greenspan was sceptical about successive legislative efforts to regulate derivatives in the 1990s. Charles A. Bowsher, head of the General Accounting Office, commenting on a report to Congress identifying significant weaknesses in the regulatory oversight of derivatives, said in testimony to the House Sub-Committee on Telecommunications and Finance in 1994 : “The sudden failure or abrupt withdrawal from trading of any of these large U.S. dealers could cause liquidity problems in the markets and could also pose risks to others, including federally insured banks and the financial system as a whole. In some cases intervention has and could result in a financial bailout paid for or guaranteed by taxpayers.” In his testimony at the time, Greenspan was reassuring. "Risks in financial markets, including derivatives markets, are being regulated by private parties. There is nothing involved in federal regulation per se which makes it superior to market regulation,” though he did accept derivatives could amplify crises because they connect together financial institutions: "The very efficiency that is involved here means that if a crisis 
were to occur, that that crisis is transmitted at a far faster pace and with some greater virulence.” When the Commodity Futures Trading Commission, the federal agency which regulates options and futures trading examined derivatives regulation in 1997, the head of the Commission, Brooksley E. Born said in testimony to Congress that such opaque trading might "threaten our regulated markets or, indeed our economy without any federal agency knowing about it,” but she was chastised for taking steps that would lead to a financial crisis by Treasury officials (New York Times 8 October 2008). The explosive potential of derivatives was always present, as the implosion of the hedge fund Long Term Capital Management (LTCM) in 1998 revealed. With equity of $\$ 4.72$ billion and debt of $\$ 124$ billion LTCM had managed to secure off-balance sheet derivative positions of $\$ 1.29$ trillion (mostly in interest rate swaps). The rescue of LTCM by a consortium of banks led by the Federal Reserve Bank of New York in order to maintain the integrity of the financial system, was a harbinger of how a decade later on massive systemic financial risk taking would be rescued by governments after the event, rather than regulated by governments before the event.

Figure 3 The Growth of Subprime Mortgages in the United States

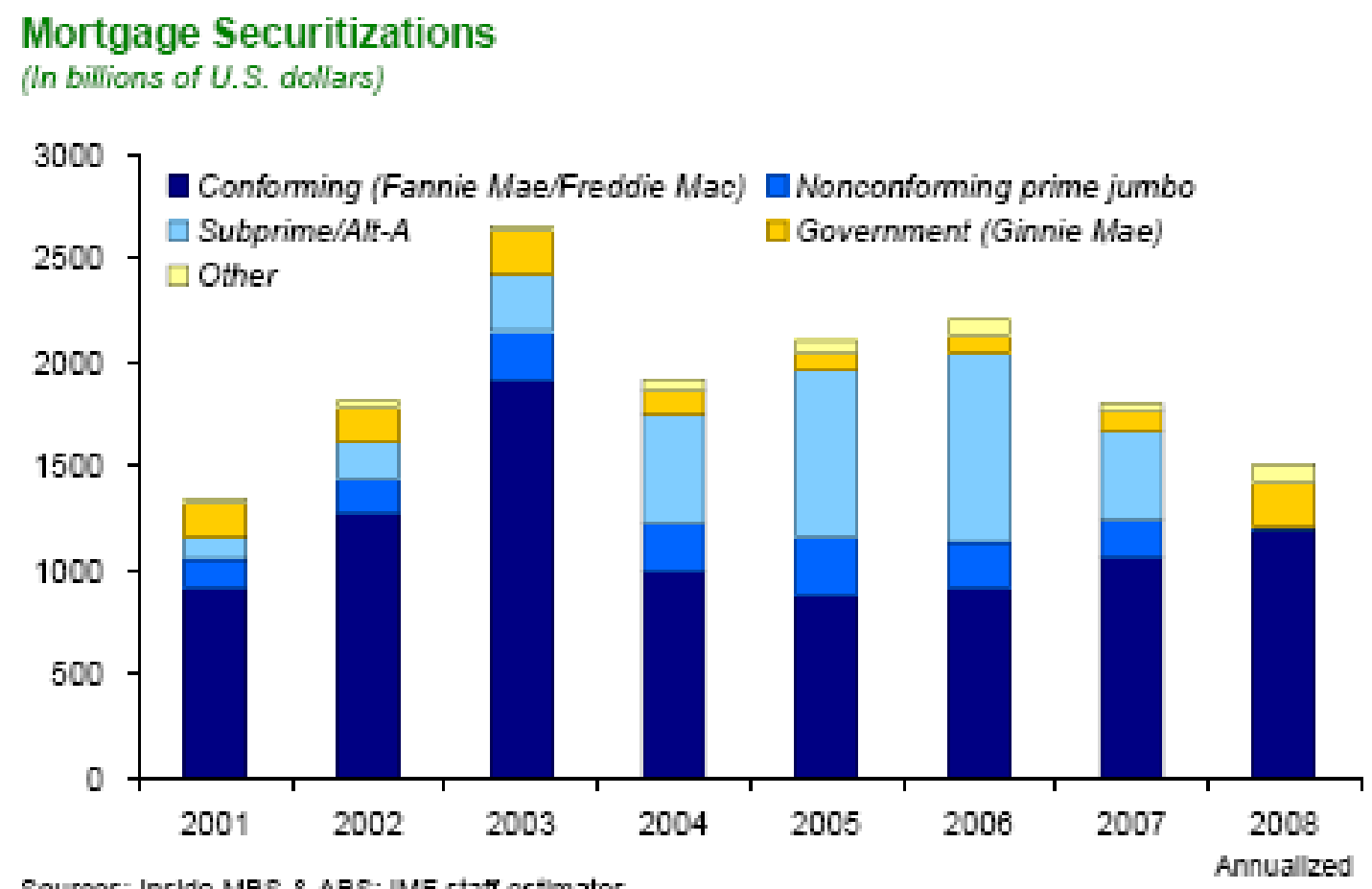




\section{The Subprime Mortgage Debacle}

The subprime mortgage phenomenon demonstrated how unconscionable risks could be taken on by investment banks, concealed in securities, and sold on to other financial institutions that had little idea of the risk they were assuming. Encouraged by a political climate in the United States that favoured extending home ownership, by the rapid inflation in the US housing market, and by the ready availability of cheap credit, mortgage companies across the United Stages began extending house loans to people with little prospect of ever repaying them. While asset prices continued to rise this problem was concealed for individuals who could borrow more money using their increased house equity as collateral. Banks did not feel exposed due to the apparently endless increase in asset values backing their loans. From 2001 subprime mortgages increased from a small segment of the market, to hundreds of billions of dollars of mortgages by 2006 (Figure 3).These mortgage contracts were sold on to larger financial institutions, who bundled them into securities in a manner that ultimately proved fatal for a significant part of the international financial system as Le Roy (2008) explains: "Securitisation becomes increasingly complicated when financial institutions chose to retain Mortgage Backed Securities (MBS), and re-securitise pools of MBS bonds into Collateralised Debt Obligations (CDOs). Securitisation becomes more complicated again when institutions create Special Investment Vehicles (SIVs), off balance sheet entities which hold pools of MBSs and CDOs and issue short and medium term debt (rather than longer term debt like most CDOs) referred to as Asset Backed Commercial Paper (ABCP) (Rosen 2007; Schwarcz 2008). It is easy to see why securitisation is seen as a “shadow banking system”, whereby off balance sheet entities and over the counter (OTC) credit instruments lie outside the reach of regulators and capital adequacy guidelines, making risk increasingly difficult to price, manage and quantify (Whalen 2008; Schwarcz 2008). The increasing complexity of securitisation and the change in lending practices to "originate to 
distribute” led to acute moral hazard, where each participant in the mortgage chain was trying to make continuously greater returns whilst assuming that they passed on all the associated risks to other participants (Lewis 2007; Ee \& Xiong 2008). Financial innovation was meant to distribute risks evenly throughout the financial system, thus reducing the risk for the system as a whole, however increased risk tolerance, moral hazard and an insatiable thirst for return pushed all participants to borrow larger sums and to take increasingly bigger bets. The result was that whilst risk was dispersed for the individual players, it was amplified for the entire financial system (Lim 2008)”.

The financial system was exposed as the US housing bubble burst as house mortgage holders exhausted the teaser low rates that had enticed them into borrowing, and were confronted by much higher rates of repayment they could not afford. With non-recursive loans in the US, mortgagees could simply walk away from their debt, posting the keys back to the bank ('jingle mail’) leaving properties in many inner urban areas to become derelict, as advancing foreclosures emptied whole neighbourhoods in some cities. This surge in mortgage defaults and foreclosures was followed by a plunge in the prices of mortgage-backed securities. The sub-prime crisis unfolded as it became apparent that sub-prime mortgages had been mixed with other assets in CDOs, somehow given double A ratings by the ratings agencies, and marketed world-wide. Innovative securities originally conceived to insulate against risk, had through misuse metastasized into the wide distribution of acutely dangerous and uncontrollable risks. Adrian Cadbury observed on this: "I suggest that there are two aspects of what went wrong. One was that in general risk was undervalued by the financial institutions. The second was that the banks simply did not know where their risks lay. Sub-prime mortgages were parcelled out by banks and sold through perhaps three or four levels of intermediary. When house prices fell people handed in their keys. The intermediaries found they were in the property business which they could not 
finance and in turn each level went bust. The banks found that they were ultimately responsible, a contingent liability they were unaware of and had not provided for. I think a sound rule is that if you do not understand the business you are getting into, don't!” The opaqueness and complexity of the financial instruments which served as a means to conceal the toxicity of the trillions of dollars of securities developed and sold by the investment banks returned to haunt them with the realization that no international financial institution fully understood how much of these subprime assets were buried in their portfolios, and the growing possibility of counter-party failure, the credit markets seized up, and banks and other financial institutions began falling over as they announced huge write downs, not only in the US, but the UK, and throughout Europe (Table 1). Instead of risk being hedged, it had become inter-connected and international, and unknown.

\section{Table 1 Subprime Losses by International Banks October 2008}

\section{US FINANCIAL INSTITUTION FAILURES}

As financial institutions, over-burdened with debt, desperately attempted to deleverage by selling assets, including the mortgage backed securities, the cruel 'paradox of deleveraging' was exposed: that the fire-sale of assets simply drives asset prices down, and left the banks in an even worse position. (Paul Volker, the former President of the US Federal Reserve, who President Obama welcomed back as an economic adviser, once referred to "the transient pleasures of extreme leverage...” ) Caught in these financial manoeuvres, one of the largest Wall Street investment banks Bear Stearns failed in March 2008, and in a deal sponsored by the US Federal Reserve was sold to JPMorgan Chase. With the collapse of a string of venerable Wall Street institutions the US Treasury, Federal Reserve, and SEC were galvanized into action, and selectively nationalized those companies thought too vital to the US financial structure to allow to fail, arranged the sale of companies that could be salvaged, or allowed companies to collapse that were thought dispensable (Appendix 1). 
In September 2008 in quick succession the two giant US mortgage corporations Fannie May (FNMA) and Freddie Mac (FHLMC) could not raise capital, and with \$5 trillion in mortgage backed securities, the US government was forced to intervene assuming a 'conservatorship' of the agencies, investing $\$ 200$ billion in preferred stock and credit. (This reversed policy establishing these government sponsored enterprises as private corporations in 1968 and 1970 respectively). Within days AIG, one of the world's largest insurance companies, which was responsible for insuring many of the securities contracts of other financial institutions, was rescued by the Federal Reserve which offered a credit facility of $\$ 85$ billion for a $79.9 \%$ equity stake (the largest government bail-out of a private company in US history, and bizarrely making the US government the major sponsor of Manchester United football club, who wore 'AIG' emblazoned on their shirts). The investment bank Lehman Brothers was the only major institution allowed to become bankrupt, with Barclay’s buying the investment arm after negotiations for Barclay’s to acquire the whole firm stalled. The consequences of this fateful decision by Henry Poulson the US Treasurer (and formerly CEO of Goldman Sachs) not to rescue Lehman’s reverberated painfully through the international financial system: as Lehman’s derivative positions were unwound, inter-bank lending froze up, and confidence in the viability of financial institutions around the world suddenly collapsed. Merrill Lynch which had racked up \$51 billion dollars in losses on asset backed securities was the third of the top five Wall Street investment banks to fail, and was sold to Bank of America for $\$ 50$ billion. Washington Mutual the sixth largest bank in the US was declared bankrupt, and JP Morgan Chase bought the banking assets from the government. Wachovia the fourth largest bank holding company was the subject of a US $\$ 15$ billion takeover from Wells Fargo contested by Citigroup.

Though this was the greatest series of government interventions in US financial markets in recent decades, the NYSE continued in free-fall, and the whole of the US banking sector appeared 
vulnerable. When selective assistance did not resolve the problem an enormous rescue operation offering up to $\$ 700$ billion to buy up toxic securities from the financial institutions in order to restore credit markets was brought by the Bush administration to a Congress reluctant about rescuing Wall Street from its own folly. The Emergency Economic Stabilisation Act 2008 authorised the US Treasurer Henry Paulson to spend up to $\$ 700$ billion purchasing distressed assets, particularly mortgage-backed securities from the banks. The purposed of the act was to purchase the toxic assets, assuring the worth of the bank's remaining assets, and restoring the confidence of the market. Reflecting the widespread public opposition to the bail-out, the House of Representatives rejected the proposal, and the Dow Jones dropped 777 points a $\$ 1.2$ trillion dollars fall in market value. Criticism of the original Poulson proposals included objection to the idea that taxpayers should bail out Wall Street; the ambiguity of objectives and lack of oversight of the new agency responsible for buying assets; the prospect of over-paying for bad assets giving the executives and investors in financial firms a windfall at taxpayers expense; and a conviction that any purchase should be of preferred stock in the banks, avoiding the problem of valuing complex assets, and offering a greater degree of control and the possibility of a more significant return from the exercise (Stiglitz 2008a; Krugman 2008). Finally a heavily amended proposal was eventually passed through Congress on 3 October 2008 giving the Treasurer immediate access to $\$ 250$ billion, following that a further $\$ 100$ billion could be authorised by the President, with Congress confirming the last $\$ 350$ billion. Transparency details were required for each transaction, and a set of oversight mechanisms involving a Financial Oversight Board, Congressional Oversight Panel, and Special Inspector General of the program. The Treasurer was required to obtain the right to purchase non-voting stock in companies that participated in the sale of assets giving the government an equity interest in the companies. The Treasury was required to maximise assistance to homeowners facing foreclosure. Finally companies participating in the scheme were prohibited from offering executives incentives to take excessive risks, or to offer 
golden parachutes to executives, and were given the right to clawback senior executive bonuses if they were later found to be based on inaccurate data. When stock markets opened the following Monday after the Act was passed, the Dow Jones was down 700 points, the FTSE down 7.9\%, the Dax down 7.1\%, and France’s CAC 40 down 9\%, revealing that markets were not going to be easily reassured, and the financial crisis was becoming internationally contagious.

\section{EUROPEAN FINANCIAL INSTITUTIONS FAILURES}

\section{Figure 4 Market Capitalization and Equity Book Values of Financial Institutions 2006-2008 (Billions of US dollars)}

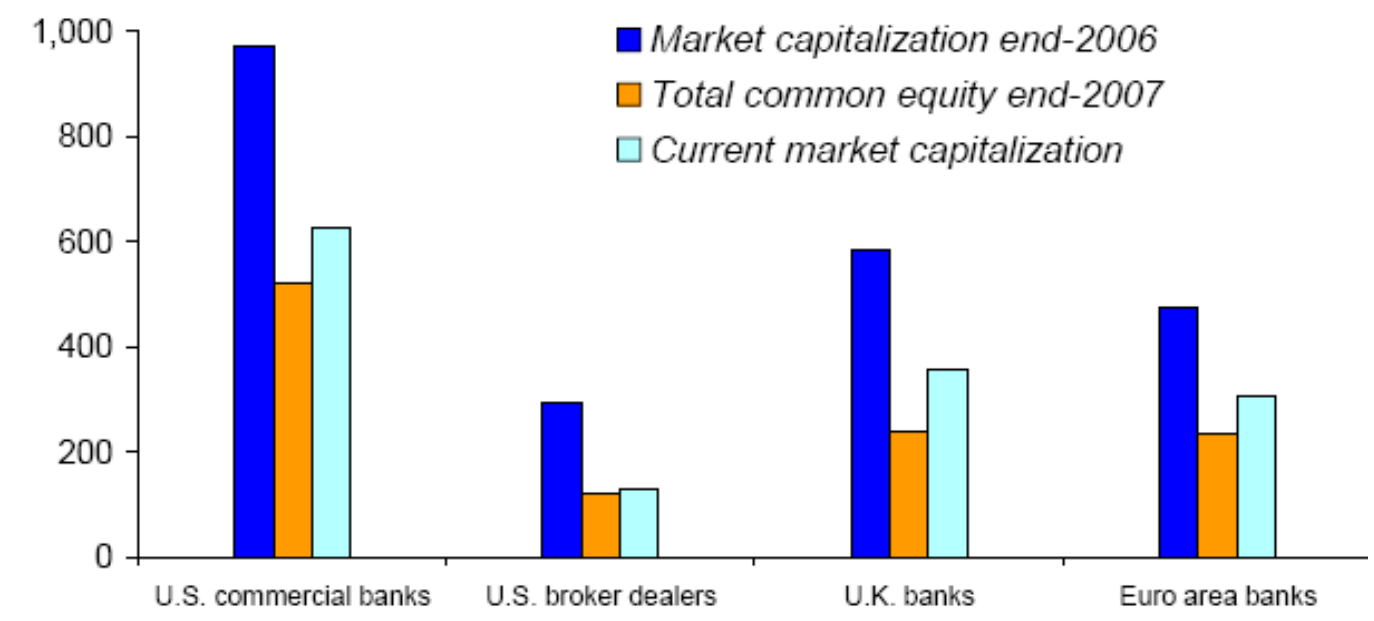

Source: Bloomberg L.P.

Note: U.S broker dealers include Lehman Brothers, Morgan Stanley, Goldman Sachs and Merrill Lynch. The other three categories, namely, U.S., U.K. and euro area banks, include institutions that have retail banking businesses in their respective regions.

Source IMF (2008a:22)

All over Europe as the contagion spread the impact of the subprime crisis was wreaking havoc in financial institutions, threatening entire financial systems, and severely undermining the fragile unity of the European Union (Appendix 1). The scale of the crisis for European financial institutions, relative to the size of the sector, was becoming just as serious as for US financial institutions (Figure 4). The first tremors of the crisis were felt in the UK, which rivals the US as the centre of the international financial system. Among the early casualties of the subprime crisis 
were Northern Rock, one of the largest mortgage lenders in the UK, which depended on the wholesale market for short term credit. Northern Rock could not raise sufficient capital in September 2007, and after a run on the bank reminiscent of the 1920s, was effectively nationalised by the UK government trying desperately to contain an impending mass public financial panic. As the credit crisis worsened for institutions used to relying on the wholesale market and inter-bank lending, a liquidity crisis gripped the major British banks, while their share prices collapsed. In September 2008 HBOS, the UK’s largest mortgage lender was sold to Lloyds TSB as the government suspended the regulations limiting maximum market share of any one bank. Bradford and Bingley, another large mortgage provider was nationalised by the government, with the sale of its savings arm to Abbey owned by the Spanish Santander. As panic selling continued on the London Stock Exchange with HBOS and Bank of Scotland bank shares losing $40 \%$ of their value in a single day’s trading, the UK government intervened with a $£ 500$ billion (US\$850) billion rescue package for eight of the largest UK banks intended to restore stability to the system. This package consisted of up to $£ 50$ billion in capital investment for the banks in exchange for preference shares, short-term loans up to $£ 200$ billion from the Bank of England, and loan guarantees for banks lending to each other of up to $£ 250$ billion. The offer of assistance was conditional on restraint in executive incentives and rewards and on dividend payments, and that banks must be able to lend to small businesses and home owners.

In other European countries the response to the crisis was largely managed on a national basis as financial institutions failed. Fortis one of the world's largest banking, insurance and investment companies was rescued by the Netherlands nationalising its Dutch operations, and France’s BNP Paribas buying its Belgian and Luxemburg operations. Dexia the Belgian financial services company was rescued by the French, Belgian, and Luxemburg governments. As the entire banking system of Iceland began to fail, the government invested $€ 600$ million for a $75 \%$ stake in 
Glitnir, the second largest bank. Finally in Germany the second largest property lender Hypo Real Estate received a $€ 50$ billion rescue coordinated by the government, including $€ 20$ billion from the Bundesbank. However the efforts of Nicolas Sarkozy as EU president to secure a coordinated response to the crisis in establishing a European fund to rescue failing banks did not meet with early success: unlike the national central banks, the European Central Bank was not a lender of last resort, simply acting as the Eurozone's monetary authority. Subsequently the announcement by Ireland and Greece, apparently followed by Germany, to guarantee all depositors savings, led other countries including Sweden and Denmark to do the same - seeming to cast aside any sense of European unity in the effort to save national banking systems. Spain established its own bail-out package, and Germany and other European countries establishing similar provisions.

Figure 5 World Exchange Market Capitalization (US \$trillion)

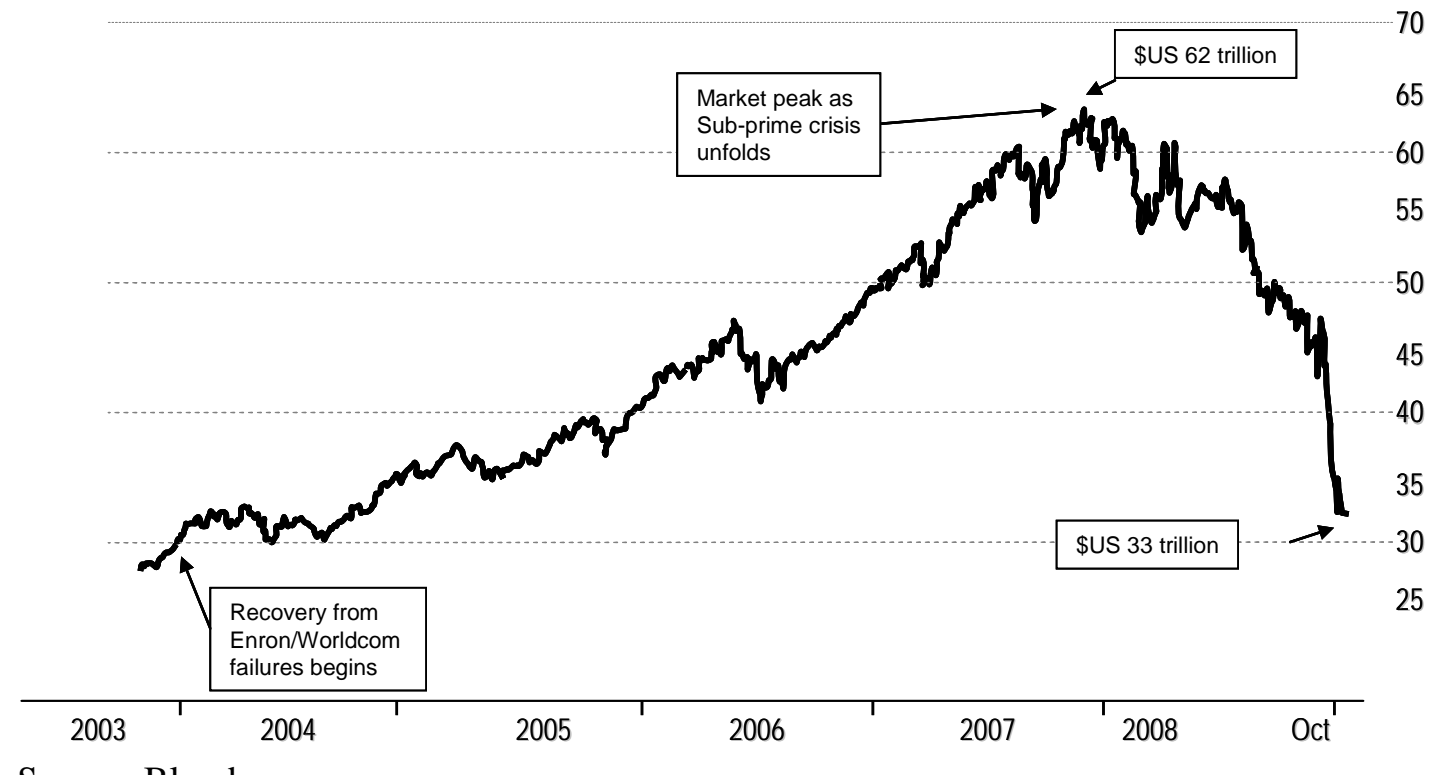

Source: Blumberg

The market capitalisation of the stock markets of the world had peaked at $\$ 62$ trillion at the end of 2007, but were by October 2008 in free fall, having lost $\$ 33$ trillion dollars, over half of their value in12 months of unrelenting financial and corporate failures (Figure 5). However in an 
unprecedented effort to provide a coordinated response, the central banks of the major industrial powers simultaneously lowered interest rates, as it became clear that a systemic response was required to a systemic crisis. As the finance ministers of the G7 countries met in emergency session in Washington, Dominique Strauss-Kahn the head of the IMF insisted, "Intensifying solvency concerns about a number of the largest US-based and European financial institutions have pushed the global financial system to the brink of systemic meltdown." The G7 ministers announced a plan to free up the flow of credit, back efforts by banks to raise money and revive the mortgage market. The 15 Eurozone leaders agreed to meet again in Paris to attempt a common approach, with Angela Merkel the German Chancellor declaring "We must redirect the markets so that they serve the people, and not ruin them” (BBC, 12 October 2008). At the meeting of 15 Eurozone countries convened by President Sarkozy the UK Prime Minister Gordon Brown was invited (the UK not being a member of the Eurozone) to explain the measures the UK government had adopted. There was agreement to implement a coordinated framework of action to take preference shares in banks and underwrite interbank lending. A few days later a meeting of all EU leaders confirmed support for this approach. Brown argued for a two stage process: “"'Stage one was to stabilise the financial system with liquidity, recapitalisation and trying to get funds moving for small businesses and consumers," he said. "Stage two is to make sure that the problems of the financial system, which started in America, do not recur." The target was to "root out irresponsibilities and excesses" in the system. "We need supervision and regulation where it has been lacking and where it is necessary, and international co-operation. We need an early warning system and proper co-ordination” (The Times 16 October 2008). The rescue package unveiled at this meeting committed the EU countries potentially to intervening with $\$ 1.8$ trillion dollars, more than double the rescue package agreed by the US Congress. 
The UK rescue package won wide acceptance among the financial community, and internationally, which led US officials to emphasise that their rescue package also allowed for the government to buy preference shares in the banks they assisted. This was a clause the Democrats in Congress had insisted on inserting into the emergency act, contrary to Poulson’s original intention to simply purchase the toxic debt of the banks. At a crucial moment in the international financial crisis it was apparent that the US government was adjusting its own policy and following Europe’s lead: “With his new initiative, Paulson appears to be conducting an aboutface with regard to his government's previous policies and to be adopting an approach similar to that being used in Europe. Paulson's original plan envisioned primarily purchasing bad mortgages and other rotten debt in order to restore trust in the financial system. The Bush administration hadn't even considered the idea of government investments -- Congress first addressed the issue in its revisions of the bailout package. According to the Wall Street Journal, the new plan largely replaces the former ideas, which failed to restore confidence, leading to dramatic decline of stock markets last week” (Spiegel Online 14 October 2008). The US government announced a \$250 billion plan to purchase stakes in a wide variety of banks in an effort to return them to solvency, with major investments of \$25 billion each in Bank of America, Citigroup, J.P. Morgan Chase, Wells Fargo, and \$10 billion investments in Goldman Sachs and Morgan Stanley.

Europe and the US had come to adopt similar strategies to address the enveloping crisis, yet with different philosophies regarding the outcome. President Bush declared, “This is an essential short-term measure to ensure the viability of America's banking system. This is not intended to take over the free market, but to preserve it.” The Treasury Secretary Henry Paulson said the lack of confidence in the financial system was a threat to the US economy, and argued that the government taking equity stakes was “objectionable to most Americans, including myself. We regret taking these actions, but we must to restore confidence in the financial system” (BBC 14 
October 2008). In contrast the President of the European Union Nicolas Sarkozy insisted "Cette crise est la crise de trop. Il faut refonder le système.... fonder un nouveau capitalisme sur des valeurs qui mettent la finance au service des entreprises et des citoyens et non l'inverse". ("This crisis is one too much; the system has to be re-established... a new capitalism based on values that place finance in the service of businesses and citizens, and not the reverse") (France Info 27

October 2008).

Figure 6 Scale of Financial Assets in Multiples of Gross Domestic Product

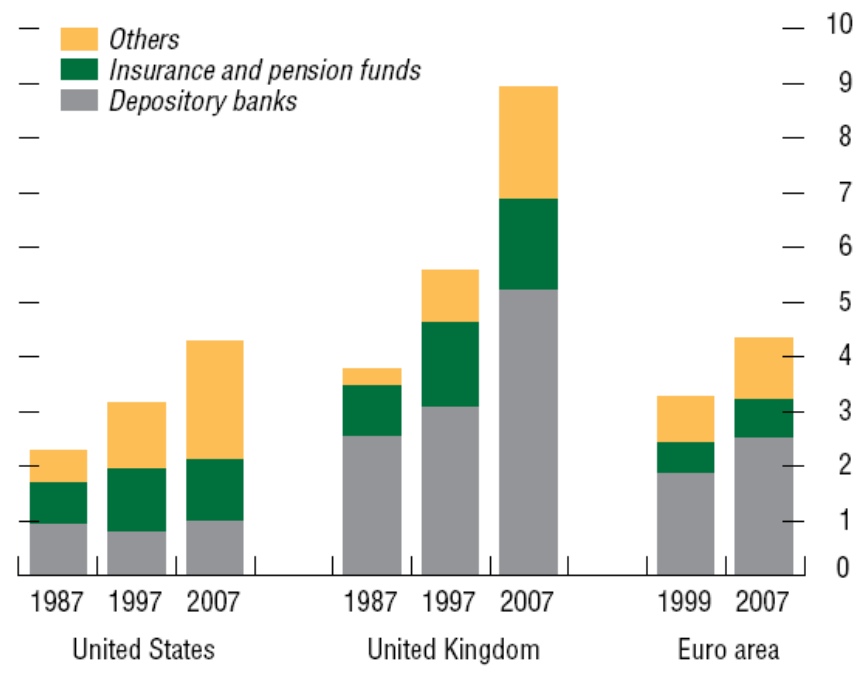

Sources: U.S. Board of Governors of the Federal Reserve System; U.K. Office of National Statistics; European Central Bank; and IMF staff estimates.

Source: IMF (2008a:68)

\section{THE FINANCIALISATION OF THE GLOBAL ECONOMY}

Directing markets was now a great deal more difficult since financial markets have become much larger, inter-connected and internationalised. A McKinsey survey illustrates how European capital markets are catching up with US markets (including equity securities, private debt securities, government debt securities, and bank deposits). "The United States remains the world's largest and most liquid capital market, with \$56 trillion in assets, or nearly one-third of the global total. But Europe’s financial markets are approaching the scale of the US markets. Including the United Kingdom, Europe’s financial markets reached \$53 trillion in 2006 - still 
less than the US total, but growing faster. Three quarters of the gain came from the deepening of Europe’s equity and private debt markets. The eurozone’s financial markets reached \$37.6 trillion, the UK markets reached \$10 trillion, and other Western European nations \$5.6 trillion. Equally important, the euro is emerging as a rival to the dollar as the world's global reserve currency, reflecting in part the growing vibrancy and depth of Europe’s financial markets. In mid-2007, the value of euro currency in circulation surpassed that of dollar notes in the world for the first time, and the euro has been the top choice in the issuance of bonds” (McKinsey 2008:1112). Relative to gross domestic product the financial sector in all of the industrial countries grew considerably in the last two decades of financial de-regulation, innovation and globalisation. The size of financial assets in both the US and UK had more than doubled in 20 years. The massive growth of the UK finance sector and also the sustained growth of the European finance sectors involved the adoption of similar financial innovation and exotic instruments as in the United States. British and European financial institutions had also succumbed to the temptations of high leverage (in some cases higher than the Wall Street investment banks), minimal risk management, and a fascination with the returns that new financial securities and speculative industries - most notably the property sector - might deliver. In the UK the financial sector became gargantuan, with assets around 9 times GDP (Figure 6), a multiple more than double that of the U.S. finance sector. A concentration on financial services was considered in the US and UK as an essential part of the new economy, and was associated with rapid market growth, high profits and very high salaries for a privileged few dealing in the most exotic financial securities. London basked in its developing reputation as the financial capital of the world, and when annual bonuses were paid in the finance sector, property prices in central London (already now among the highest in the world) jumped again (City of London 2008). 
Fuelling the whole process of financialisation were volcanic eruptions of debt. When Alan Greenspan became Chairman of the Federal Reserve in 1987 public and private debt in the US totalled \$10.5 trillion, but after his departure in 2006 it had quadruped to \$43 trillion. “Debt in record quantities had been piled on top of the trillions still extant from previous binges of the eighties and nineties, so that by 2007 the nations overseers watched a US economy in which public and private indebtedness was three times bigger than that year's gross national product. This ratio topped the prior record, set during the years after the stock market crash of 1929. However, in contrast to the 1920s and 1930s when manufacturing retained its overwhelming primacy despite the economy's temporary froth of stockmarket and ballyhoo, the eighties and nineties brought a much deeper transformation. Goods production lost the two-to-one edge in GDP it had enjoyed in the seventies. In 2005, on the cusp of Greenspan’s retirement, financial services - the new ubercategory spanning finance, insurance and real estate - far exceeded other sectors taking over one-fifth of GDP against manufacturing's gaunt, shrunken 12 per cent. During the two previous decades (and only marginally stalled by the early 1990s economic bailouts) the baton of economic leadership had been passed” (Phillips 2008:5).

A debate has continued for some time about the costs and benefits of the financialisation of advanced industrial economies (Epstein 2005; Erturk et al 2008; Froud and Johal 2008; Froud et al 2006; Langley 2008; Martin 2002). Competing definitions of 'financialisation’ include:

- the ascendancy of 'shareholder value' as a mode of corporate governance (Aglietta and Reberioux 2005);

- the growing dominance of capital market financial systems over bank-based financial systems;

- the increasing political and economic power of a particular class grouping: the rentier class for some (Hilferding 1985); 
- the explosion of financial trading with a myriad of new financial instruments;

- the "pattern of accumulation in which profit making occurs increasingly through financial channels rather than through trade and commodity production’ (Krippner 2005);

- the increasing role of financial motives, financial markets, financial actors and financial institutions in the operation of the domestic and international economies (Epstein 2005:3).

There were many critics of financialisation, and the long progression of financial crises around the world served as a reminder that the system was neither self-regulating or robust (Laeven and Valencia 2008). However few imagined that the international financial system might prove so willfully self-destructive as this 2008 crisis revealed. "You've seen the triumph of greed over integrity; the triumph of speculation over value creation; the triumph of the short term over long term sustainable growth” was the verdict of Australia’s Prime Minister, Kevin Rudd (The Australian 6 October 2008). More forcefully still, the Archbishop of Canterbury Rowan Williams argued, "Trading the debts of others without accountability has been the motor of astronomical financial gain for many in recent years... The crisis exposes the element of basic unreality in the situation - the truth that almost unimaginable wealth has been generated by equally unimaginable levels of fiction, paper transactions with no concrete outcome beyond profit for traders.. The biggest challenge in the present crisis is whether we can recover some sense of the connection between money and material reality - the production of specific things, the achievement of recognisable human goals that have something to do with a shared sense of what is good for the human community in the widest sense.” (The Spectator 27 September 2008).

\section{THE CORPORATE GOVERNANCE CAUSES OF THE CRISIS}

The explanation of why investment banks and other financial institutions took such spectacular risks with extremely leveraged positions on many securities and derivatives, and the risk 
management, governance and ethical environment that allowed such conduct to take place is worth further analysis. Nobody imagined the scale of the tragedy that befell Wall Streets leading investment banks. “Wall Street: RIP,” pronounced The New York Times (28/9/2008). “A world of big egos. A world where people love to roll the dice with borrowed money, of tightwire trading, propelled by computers... that world is largely coming to an end.” Replacing the triumphal past was disillusion and disorientation: "Enthusiasm was gone from Wall Street yesterday, replaced by a febrile uncertainty and a foreboding that 2008 might turn into 1929” (Times Online 1 October 2008). No one had imagined this all could happen this quickly, or could anticipate when it might end. On the 18 November 2008 Henry Poulson told Congress he is handing over to President-elect Barak Obama "A signficantly more stable banking system, where the failure of a systemically relevant institution is no longer a pressing concern rattling the markets.” The following day the second largest bank in the United States Citigroup’s shares went into free-fall losing $20 \%$ of their value each day until the Treasury and Federal Reserve agreed a rescue package of over $\$ 300$ billion.

\section{De-regulation}

Financial institutions are critical to the operation of any economy, and traditionally subject to a framework of firm regulation, however as the financialisation of the US and international economy proceeded, paradoxically the regulatory touch lightened considerably. In the words of one US finance expert, in the years before the crisis "We were developing a system of very large, highly levered, undercapitalised financial institutions - including the investment banks, some large money centre banks, the insurance companies with large derivative books and the government-sponsored entities...Regulators believe that all of these are too big to fail and would bail them out if necessary. The owners, employees and creditors of these institutions are rewarded when they succeed, but it is all of us - the taxpayers - who are left on the hook if they 
fail. This is called private profits and socialised risk. Heads I win. Tails, you lose. It is a reverse Robin Hood system” (Einhorn 2008:16-17).

The abolition of the Glass-Steagall Act in 1999 paved the way for a regulatory loosening of the US financial system, enhanced in 2004 by a new SEC rule intended to reduce regulatory costs for broker-dealers that were part of consolidated supervised entities. Essentially this involved large broker-dealers using their own risk-management practices for regulatory purposes enabling a lowering of their capital requirements (the core capital which a bank is required to hold to support its risk-taking activities which normally includes share capital, share premium, and retained earnings). In addition the SEC amended the definition of net capital to include securities for which there was no ready market, and to include hybrid capital instruments and certain deferred tax assets, reducing the amount of capital required to engage in high risk activities. Finally the rule eased the calculations of counter-party risk, maximum potential exposures, margin lending, and allowed broker-dealers to assign their own credit ratings to unrated companies. Einhorn comments on this regulatory capitulation of the SEC "Large broker-dealers convinced the regulators that the dealers could better measure their own risks, and with fancy math, they attempted to show that they could support more risk with less capital. I suspect that the SEC took the point of view that these were all large, well-capitalised institutions, with smart, sophisticated risk managers who had no incentive to try to fail. Consequently, they gave the industry the benefit of the doubt” (2008:16).

\section{Ratings Agencies}

As international financial markets have expanded the role of the credit ratings agencies (CRAs) have proved critical. The International Organisation of Securities Commissions (IOSCO) claims that "CRAs assess the credit risk of corporate or government borrowers and issuers of fixedincome securities. CRAs attempt to make sense of the vast amount of information available 
regarding an issuer or borrower, its market and its economic circumstances in order to give investors and lenders a better understanding of the risks they face when lending to a particular borrower or when purchasing an issuer's fixed-income securities. A credit rating, typically, is a CRA's opinion of how likely an issuer is to repay, in a timely fashion, a particular debt or financial obligation, or its debts generally” (2003:1). Yet the question asked by everybody when the financial crisis erupted was how could asset backed securities containing subprime mortgages and other high risk debt possibly be given AA credit ratings by Standard and Poor's or Moody’s? The answer was again that financial innovation had outpaced regulatory prowess. The ratings agencies instead of monitoring rigorously the growth of financial markets and instruments had become junior partners in this enterprise. Coffee (2006) in his critique of the failure of the gatekeeper professions in US corporate governance including auditors, corporate lawyers, and securities analysts, raises the following issues regarding rating agencies:

\section{i) Concentration}

Given the immense capacity of the ratings agencies to influence the fortunes of financial institutions and instruments in terms of the public perception of risk, they have maintained a highly profitable duopoly with Standard and Poor's Ratings Services and Moody’s Investor Services, only recently joined by Fitch Investor services for specialised submarkets. The SEC has supported this entrenched market position, reinforced by a reputational capital only now being challenged.

\section{ii) Conflicts of Interest}

Traditionally the ratings agencies rated thousands of clients in the corporate debt business with little chance of being captured by single clients. However as the importance of the structured debt market grew, there were only a few investment banks active but the scale of the market grew exponentially. From the 1970s the ratings agencies business changed from 
their revenue coming from subscribers for their ratings services, to their revenue coming from the issuers of debt products, creating a context for capture by client’s interests.

\section{iii) Complex Financial Products}

Rating corporate debt utilising corporate financial history, audited financial statements, is less difficult than complex structured finance products issued by investment banks. Understanding the nature of the underlying assets and cash flows generated by these assets and the risks involved over time is a major undertaking. The ratings agencies deny any obligation to do due diligence on the portfolio backing structured finance products.

\section{iv) Timing and Relevance}

Even if the ratings agencies were close in their original rating, they do not review how a debt product may change over time in different market conditions, and rating agencies were slow to downgrade subprime asset backed securities (Scott 2008 23-24; Coffee 2006).

The ratings agencies believed in the investment banks of Wall Street, and in their risk controls, and assumed that 'everything was hedged.' Though the CRAs do have the power to review nonpublic information to assess the credit-worthiness of institutions and securities, they did not have the inclination, manpower or skills to do this thoroughly in all cases, and they did not get paid until they gave a rating. "The market perceives the rating agencies to be doing much more than they actually do. The agencies themselves don’t directly misinform the market, but they don’t disabuse the market of misperceptions — often spread by the rated entities — that the agencies do more than they actually do. This creates a false sense of security, and in times of stress, this

actually makes the problems worse. Had the credit rating agencies been doing a reasonable job of disciplining the investment banks — which unfortunately happen to bring the rating agencies lots of other business — then the banks may have been prevented from taking excess risk and the current crisis might have been averted” (Einhorn 2008:13).

\section{Risk Management}


Financial businesses activities in rapidly changing markets are highly sensitive to variance, and it might be expected that as the financial services industries have grown inexorably and financial products become more complex, that the sophistication of risk management techniques will have developed in parallel. However the reality is that innovation in financial products has far exceeded the capacity of risk management measurement and monitoring tools to gauge risk. The most widely employed risk management tool is value-at risk (VaR), which measures how much a portfolio stands to make or lose in $99 \%$ of the days. But as Einhorn argues this measure ignores what might happen at the moment of greatest risk: “A risk manager’s job is to worry about whether the bank is putting itself at risk in the unusual times — or, in statistical terms, in the tails of distribution. Yet, VaR ignores what happens in the tails. It specifically cuts them off. A 99\% VaR calculation does not evaluate what happens in the last $1 \%$. This, in my view, makes VaR relatively useless as a risk management tool and potentially catastrophic when its use creates a false sense of security among senior managers and watchdogs. This is like an airbag that works all the time, except when you have a car accident. By ignoring the tails, VaR creates an incentive to take excessive but remote risks”(Einhorn 2008:11). Yet VaR was the tool international finance industries relied upon in transactions involving billions of dollars. For example UBS was the European bank with the largest losses from the crisis, involving the Swiss government and central bank providing an aid package of $\$ 59.2$ billion to take risky debt securities from its balance sheet. In a report to shareholders published in April 2008 UBS laid bare the risk management failings that had led to such immense losses. (Though wealthy clients continued to desert the bank in droves, withdrawing $\$ 58$ billion in the third quarter of 2008). The report highlights in worrying detail the incomplete risk control methodologies, with market risk control (MRC) placing considerable reliance on VaR and stress limits to control the risks of the business, without implementing additional risk methodologies, or aggregating notional limits even when losses were made (2008:13): 
i) Mortgage portfolio trades were certified by the UBS investment bank’s quantitative risk control "But with the benefit of hindsight appears not have been subject to sufficiently robust stress testing. Further, the collateralised debt obligation desk did not carry out sufficient fundamental analysis as market conditions deteriorated...” (2008:30).

ii) With regard to asset backed securities trading also there were incomplete risk control methodologies. "There was considerable reliance on AA/AAA ratings and sector concentration limits which did not take into account the fact that more than $95 \%$ of the asset backed securities trading portfolio was referencing US underlying assets (i.e. mortgage loans, auto loans, credit card debt etc)" (2008:32).

iii) In fixed income there was a growth orientation: "The investment bank was focused on the maximisation of revenue. There appears to have been a lack of challenge on the risk and reward to business area plans within the investment bank at a senior level. UBS's review suggests an asymmetric focus in the investment bank senior management meetings on revenue and profit and loss, especially when compared to discussion of risk issues. Business-peer challenge was not a routine practice in those meetings...Inappropriate risk metrics were used in strategic planning and assessment. Investment Bank planning relied on VaR, which appears as the key risk parameter in the planning process. When the market dislocation unfolded, it became apparent that this risk measure methodology had not appropriately captured the risk inherent in the business having subprime exposures”(2008:34).

iv) With regard to UBS group governance there was: "Failure to demand a holistic assessment. Whilst group senior management was alert to the general issues concerning the deteriorating US housing market, they did not demand a holistic presentation of UBS's exposure to securities referencing US real estate assets before July 2007, even though such an assessment may have been warranted earlier in view of the size of UBS's real estate assets” (2008:35). 
v) The report concluded with reference to risk control that there was over-reliance on VaR and stress: "MRC relied on VaR and stress numbers, even though delinquency rates were increasing and origination standards were falling in the US mortgage market. It continued to do so throughout the build-up of significant positions in subprime assets that were only partially hedged. Presentations of MRC to UBS’s senior governance bodies did not provide adequate granularity of subprime positions UBS held in its various businesses. No warnings were given to group senior management about the limitations of the presented numbers or the need to look at the broader contextual framework and the findings were not challenged with perseverance” (2008:39).

vi) Finally the report condemned the lack of independence and healthy scepticism in UBS governance: "Fundamental analysis of the subprime market seems to have been generally based on the business view and less on MRC’s independent assessment. In particular there is no indication that MRC was seeking views from other sources than business...Further, risk systems and infrastructure were not improved because of a willingness by the risk function to support growth” (2008:39-40).

\section{Incentivisation}

The final and most critical part of the explanation of why investment banks and other financial institutions took such extreme risks with highly leveraged positions in complex securities, neglecting risk management, governance principles, and often basic business ethics, was that they were highly incentivised to do so. Massively incentivised irresponsibility became the operating compensation norm in the financial community, as banks and fringe financial institutions chased the super profits available as global financial markets expanded exponentially. "The management teams at the investment banks did exactly what they were incentivized to do: maximize employee compensation. Investment banks pay out $50 \%$ of revenues as compensation. So, more leverage means more revenues, which means more compensation. In good times, once they pay out the 
compensation, overhead and taxes, only a fraction of the incremental revenues fall to the bottom line for shareholders. The banks have done a wonderful job at public relations. Everyone knows about the $20 \%$ incentive fees in the hedge fund and private equity industry. Nobody talks about the investment banks’ 50\% compensation structures, which have no high-water mark and actually are exceeded in difficult times in order to retain talent”(Einhorn 2008:11). The report on the vast write-downs at UBS examines how the compensation structure directly generated the behaviour which caused the losses, as staff were motivated to utilise the low cost of funding to invest in subprime positions. "Employee incentivisation arrangements did not differentiate between return generated by skill in creating additional returns versus returns made from exploiting UBS’s comparatively low cost of funding in what were essentially carry trades...The relatively high yield attributable to subprime made this asset class an attractive long position for carry trades. Further, the UBS funding framework amplified the incentives to pursue compensation through profitable carry trades. The compensation structure generally made little recognition of risk issues or adjustment for risk/other qualitative indicators (e.g. for group internal audit ratings, operational risk indicators, compliance issues etc.)” As a result there were insufficient incentives to protect the UBS franchise for the longer term "it remains the case that bonus payments for successful and senior international business fixed income traders, including those in the businesses holding subprime positions were significant. Essentially, bonuses were measured against gross revenue after personnel costs, with no formal account taken of the quality and sustainability of those earnings" (2008:42).

\section{REGULATION AND GOVERNANCE OF FINANCIAL INSTITUTIONS}

While the accumulated cost of the global financial crisis was being realised the commitment to establish a new international financial regulatory framework increased. As the costs of all forms of intervention to alleviate the crisis by the US government ballooned out to $\$ 7.7$ trillion dollars 
(including credit discounts, credit extensions, securities lending, term auction facilities, portfolio funding, money market funding, TARP, assistance to specific institutions, economic stimulus packages, and homeowner assistance), The general market assistance and specific rescue packages for individual financial institutions amounted to almost $\$ 11$ trillion worldwide by October 2008 (Table 2). While these funds could be regarded as a temporary investment in the financial economy, with the hope of recouping much of the funds back at a later stage, this was an optimistic view when the crisis spread to other sectors of the economy. As the financial crisis impacted upon the real economy the fears of a prolonged recession grew, with US industrial production falling further than it had for over 30 years, and for example the US automotive industry becoming increasingly precarious announcing further major redundancies and looking for support from the federal government (including support from the assistance intended for financial institutions, since the automotive companies had also become finance companies). The International Labour Organisation in Geneva estimated that up to 20 million people in the world would lose their employment as a consequence of the financial crisis, and that for the first time in a decade the global total of unemployed would be above 200 million (Associated Press, 21 October 2008). The prospect of the whole world falling into recession at the same time became possible, something not witnessed since the 1930s.

\section{Table 2 Government Support for Global Financial Crisis 2008}

There was a widespread sense that this regulatory failure of financial markets could not be allowed to occur again. Chancellor of Germany, usually a stalwart ally of President Bush, derided the lack of regulation that, in her view, allowed the financial crisis to erupt in the United States and seep inexorably toward Europe. She reminded the German public that the United States and Britain rejected her proposals in 2007 for regulating international hedge funds and bond rating agencies. "It was said for a long time, 'Let the markets take care of themselves,' " Merkel commented. Now, she added, "even America and Britain are saying, 'Yes, we need more 
transparency, we need better standards.' " Germany's finance minister, Peer Steinbrueck, said that the "Anglo-Saxon" capitalist system had run its course and that "new rules of the road" are needed, including greater global regulation of capital markets (Washington Post 28 September 2008). Gordon Brown and Nicolas Sarkozy called for a Bretton Woods agreement for the $21^{\text {st }}$ century, aimed at rebuilding the international financial system. Though the economic summit meeting of leaders of the G20 countries was arranged for Washington in November 2008, it was clear George Bush would not be taking the lead in this initiative. Yet something of a sea-change was occurring in American domestic politics in response to the financial crisis and with the sweeping election to the US presidency of Barak Obama. The experience of Congress and the White House equivocating about a rescue package of buying securities had made a deeply unfavourable impression on the US public. The UK government had recognized the deeper problem of a lack of confidence in the banks themselves, which was resolved by governments becoming the investor of last resort and the guarantor of loans between banks, and it was the adoption of a similar strategy by the US government that finally staunched the panic on Wall

Street. As Andrew Moravcsik, professor of politics and international affairs at Princeton University suggested “Americans, especially conservatives, have a particular view of Europe as over-regulated, therefore suffering from weak growth and Euro-sclerosis. This could change that view and create more respect the European view of regulation more generally” (Australian Financial Review 20 October 2008).

A problem in devising a new financial regulatory architecture was that Bretton Woods in 1944, though it established the International Monetary Fund and World Bank, was essentially dealing with national financial markets. Digital and interconnected global financial markets presented a much bigger challenge. A series of measures were proposed by Gordon Brown: 
i) Improving risk disclosure by financial institutions was fundamental, together with stricter rules on bank liquidity and leveraging.

ii) Ensuring banks take bigger stakes in any loans they pass on to others through securitization might constrain irresponsible innovations.

iii) Establishing a central clearing house for complex derivatives could help to discipline their use.

iv) Increased supervision and regulation might include new standards for off-balance sheet accounting, and supervision of the largest international banks and insurance companies.

v) Reforming executive compensation structures that encouraged excessive risk-taking, and aligning reward with long term value creation was another imperative.

vi) Finally a capacity to police the potential for future dangers to the international economy, and the means of cooperation for future crises were important (The Times 16 October 2008).

These principles for reforming international financial market were broadly supported in Europe, and had public resonance in the United States where it was argued the rapid expansion of unregulated financial institutions and instruments from hedge funds to credit default swaps should be contained by extending financial reserve requirements, limiting leveraging, and ensuring trading occurred on public exchanges (Wall Street Journal 25 July 2008; IPS 2008). With the international financial community still in a state of profound shock, and heavily dependent upon state aid, any protests about the dangers of over-regulation were muted. Adair Turner head of the Financial Services Authority (FSA) in the UK (responsible for regulating financial institutions) commented, "If a year and a half ago, the FSA had wanted higher capital adequacy, more information on liquidity, had said it was worried about the business models at 
Bradford \& Bingley and Northern Rock, and had wanted to ask questions about remuneration, the fact is that we would have been strongly criticised for harming the competitiveness of the City of London, red tape, and over regulation. We are now in a different environment. We shouldn't regulate for it's own sake, but over-regulation and red tape has been used as a polemical bludgeon. We have probably been over-deferential to that rhetoric" (Guardian, 16 October 2008).

However the question is, will the deference of regulators return when financial markets recover, and financial institutions and markets are free again to pursue their self-interest? An early indication of how entrenched the irresponsibility of the financial sector had become was the astonishing news that the surviving US financial institutions were preparing to pay 2008 end of year executive bonuses approximately equivalent to the billions of dollars of aid they had just received from Congress. While the US economy was collapsing around them, and the US public were becoming increasingly concerned how they might survive a severe recession, the executives of major banks seemed focused primarily on maintaining their bonuses.

\section{REFERENCES}

Amble, B (2003) The Diversity of Modern Capitalism, Oxford University Press

Aglietta,M. and Berrebi,L. (2007) Désordres Dans Le Capitalisme Mondiale, Paris: Odile Jacob. Aglietta, M. and Reberioux, A. (2005) Corporate Governance Adrift: A Critique of Shareholder Value (Cheltenham: Edward Elgar).

Chesnais,F. (2008), Fin d'un cycle. Sur la portée et le cheminement de la crise financière. Carré Rouge - La Brèche, 1: 17-31, January

Clarke, T. (2009) A Critique of the Anglo-American Model of Corporate Governance, Economy and Society

City of London (2008) The Global Financial Centres Index, Guildhall www.cityoflondon.gov.uk/economicresearch

Coffee, J. (2006) Gatekeepers: The Professions and Corporate Governance, Oxford University Press 
CTR/CEPS (2005) Deep Integration: How Transatlantic Markets are Leading Globalization, Centre for Transatlantic Relations/Centre for European Policy Studies, Washington D.C.: John Hopkins University

Ee, K., Xiong, K., 2008, “Asia: A Perspective on the Subprime Crisis”, International Monetary Fund, June 2008, Volume 45, Number 2, Last accessed 1 November 2008, http://www.imf.org/external/pubs/ft/fandd/2008/06/khor.htm

Einhorn, D. (2008) Private Profits and Socialised Risk, Global Association of Risk Professionals Review, June/July, Issue 42, pp 10-18

Einhorn, D. (2008b) Fooling Some of the People All of the Time: A Long Short Story, Hoboken, New Jersey Wiley

EPI (2008) The State of Working America, Washington: Economic Policy Insitute

Epstein, G.A. (2005) Financialization and the World Economy, Northampton MA: Edward Elgar

Erturk, I., Froud, J., Johal, S., Leaver, A. and Williams, K. (eds) (2008) Financialization at Work: Key Texts and Commentary (London: Routledge).

Fleckenstein, F. (2008) Greenspan's Bubbles: The Age of Ignorance at the Federal Reserve, New York: McGraw Hill

Froud, J., Johal, S., Leaver, A. and Williams, K. (2006) Financialization and Strategy: Narrative and Numbers (London: Routledge).

Froud, J. and Johal, S. (2008) Questioning Finance, Competition and Change, Vol 12, No 2, June 2008

Galbraith, J.K. (1993) A Short History of Financial Euphoria, London: Penguin

Goodman, P. (2008) Taking a Hard New Look at the Greenspan Legacy, New York Times, 8 October 2008

Greenspan, A. (2004) Risk and Uncertainty in Monetary Policy. American Economic Association, San Diego, California January 3, 2004, Federal Reserve Board http://www.federalreserve.gov/BoardDocs/Speeches/2004/20040103/default.htm

Hilferding, R. (1985) Finance Capital: Study of the Latest Phase of Capitalist Development, London and New York: Routledge (original edition 1910)

IFSL (2008) International Financial Markets in the UK, International Financial Services London IMF (2002) The Globalization of Finance, Finance and Development, Washington: International Monetary Fund 39,1

IMF (2008) Global Financial Stability Report: Financial Stress and Deleveraging, Washington: International Monetary Fund 
IPS (2008) A Sensible Plan for Recovery, Washington: Institute for Policy Studies, 15 October 2008

IOSCO (2003)

Janszen, E. (2008) The next bubble: Priming the markets for tomorrow's big crash, Harper's Magazine, February, 39-45

Krippner G. R. (2005) “The Financialization of the American Economy.” Socio-Economic Review 3: 173-208.

Krippner, G.R. (forthcoming) The Fictitious Economy: Financialization, the State, and the Remaking of American Capitalism.

Krugman, P. (2008) Cash for Trash, New York Times, 21 September 2008

Laeven, L. and Valencia, F. (2008) Systemic Banking Crises: A New Database, IMF Working Paper, WP/08/224, Washington DC: International Monetary Fund

Langley, P. (2008) The Everyday Life of Global Finance: Saving and Borrowing in AngloAmerica (Oxford: Oxford University Press).

Le Roy,P. (2008) The Subprime Mortgage Crisis: Highlighting the Need for Better Corporate Governance, University of Technology, Sydney

Lewis, H., 2007, “'Moral hazard' helps shape mortgage mess”, 18 April 2007, Last accessed 10 November 2008, http://www.bankrate.com/brm/news/mortgages/20070418_subprime_mortgage_morality_a1.asp? caret $=3 \mathrm{c}$

Lim, M., 2008, “Old Wine in a New Bottle: Subprime Mortgage Crisis-Causes and Consequences”, Working Paper No. 532, The Levy Economics Institute, April 2008

Lockhart, D., 2008,’The Subprime Crisis: Is It Contagious?”, Federal Reserve Bank of Atlanta, 29 February 2008, Last accessed 10 November 2008, http://www.frbatlanta.org/invoke.cfm?objectid=65C8B587-5056-9F12125B76D448344BEF\&method=display

Martin, R. (2002) The Financialization of Daily Life (Philadelphia, PA: Temple University Press).

McAvoy, P. W. and I. M. Millstein (2004) The Recurrent Crisis In Corporate Governance, Stanford Business Books.

McKinsey and Company (2008) Mapping Global Capital Markets, Fourth Annual Report, San Francisco: McKinsey Global Institute

Maximus,F. (2008), Consequences Of A Long, Deep Recession - Parts I, II, III. http://fabiusmaximus.wordpress.com/2008/06/18/consequences-1/ -2, -3. June 18-20. 
Muolo,P. and Padilla, M. (2008) Chain of Blame: How Wall Street Caused the Mortgage and Credit Crisis, Hoboken, New Jersey:Wiley

Narayanan, M.P. (1985), “Managerial incentives for short-term results”, Journal of Finance 40(5):1469-1484.

Patel, B., 2008,”Credit Crisis and Corporate Governance Implications: Guidance for Proxy Season and Insight into Best Practices”, RiskMetrics Group, April 2008, Last accessed 1 Nov 2008

http://www.riskmetrics.com//system/files/private/CreditCrisisCorporateGovernance20080408.pdf

Phillips, K. (2008) Reckless Finance Bad Money: Reckless Finance, Failed Politics, and the Global Crisis of American Capitalism, New York: Viking Books

Rosen, R., 2007, “The role of securitization in mortgage lending”, Chicago Fed, 11 October 2007, Last accessed 10 November 2008, http://www.chicagofed.org/publications/fedletter/cflnovember2007_244.pdf

Scott,W.A. (2008) The Credit Crunch and the Law - A Commentary on Economic and Policy Issues, in, R.P. Austin (editor), The Credit Crunch and the Law, Monograph 5, Ross Parsons Centre of Commercial, Corporate and Taxation Law, University of Sydney

Shiller, R. (2008) The Subprime Solution: How Today’s Global Financial Crisis Happened and What to Do About It, Princeton University Press

Soros, G. (2008) The New Paradigm for Financial Markets: The Credit Crisis of 2008 and What it Means, New York: Public Affairs

Stiglitz, J. (2008a) Realign Wall Street’s Interests, Harpers Magazine, November, 36-37

Stiglitz, J. (2008b) Henry Paulson’s Shell Game, The Nation, 26 September 2008

Schwarcz, S., 2008, “Disclosure's Failure in the Subprime Mortgage Crisis”, Research Paper Series, Research Paper No. 203, Duke Law School, March 2008

UBS (2008) Shareholder Report on UBS's Write Downs, Zurich: UBS AG www.ubs.com/1/ShowMedia/investors/shareholderreport?contentId=140333\&name=080418Shar eholderReport.pdf

Whalen, C., 2008, “The Subprime Crisis - Cause, Effect and Consequences”, Networks Financial Institute, Indiana State University, March 2008

Table 1 Subprime Losses by International Banks October 2008

\begin{tabular}{|l|l|l|l|}
\hline \multicolumn{2}{|c}{ Company } & Country & (bn \$US ) \\
\hline 1 & Citigroup & US & 66.6 \\
\hline 2 & Wachovia & US & 52.7 \\
\hline 3 & Merrill Lynch & US & 54.6 \\
\hline 4 & Washington Mutual & US & 45.6 \\
\hline
\end{tabular}




\begin{tabular}{|c|c|c|c|}
\hline 5 & UBS & Switzerland & 44.2 \\
\hline 6 & HSBC & UK & 27.4 \\
\hline 7 & Bank of America & US & 21.2 \\
\hline 8 & JP Morgan Chase & US & 18.8 \\
\hline 9 & Morgan Stanley & US & 15.7 \\
\hline 10 & IKB Deutsche & Germany & 14.7 \\
\hline 11 & Royal Bank of Scotland & UK & 16.5 \\
\hline 12 & Lehman Brothers & US & 18.2 \\
\hline 13 & AIG & US & 16.8 \\
\hline 14 & Fannie Mae & US & 12.7 \\
\hline 15 & Deutsche Bank & Germany & 11.4 \\
\hline 16 & Ambac & US & 10.3 \\
\hline 17 & Wells Fargo & US & 10 \\
\hline 18 & MBIA Inc & US & 9.4 \\
\hline 19 & Barclays & UK & 9.2 \\
\hline 20 & Credit Agricole & France & 8.6 \\
\hline 21 & Credit Suisse & Switzerland & 8.1 \\
\hline 22 & HBOS & UK & 7.5 \\
\hline 23 & Canadian Imperial Bank of Commerce & Canada & 7.1 \\
\hline 24 & Fortis & $\begin{array}{l}\text { Belgium/ } \\
\text { Netherlands }\end{array}$ & 6.9 \\
\hline 25 & Bayerische Landesbank & Germany & 6.7 \\
\hline 26 & Freddie Mac & US & 6.7 \\
\hline 27 & ING & Netherlands & 6.5 \\
\hline 28 & Societe Generale & France & 6.4 \\
\hline 29 & Mizuho Financial Group & Japan & 6.2 \\
\hline 30 & Dresdner Bank & Germany & 5 \\
\hline 31 & Bear Sterns & US & 3.4 \\
\hline 32 & WestLB & Germany & 3.1 \\
\hline 33 & BNP Paribas & France & 2.7 \\
\hline 34 & UniCredit & Italy & 2.7 \\
\hline 35 & Lloyds TSB & UK & 2.6 \\
\hline 36 & Nomura Holdings & Japam & 2.5 \\
\hline 37 & DZ Bank & Germany & 2 \\
\hline 38 & Natixis & France & 2 \\
\hline 39 & Swiss Re & Switzerland & 1.8 \\
\hline 40 & HSH Nordbank & Germany & 1.7 \\
\hline 41 & LBBW & Germany & 1.7 \\
\hline 42 & Commerzbank & Germany & 1.2 \\
\hline 43 & Mitsubishi UFJ & Japan & 1.2 \\
\hline 44 & Sumitomo & Japan & 1.2 \\
\hline \multirow[t]{2}{*}{45} & AXA & France & 1.1 \\
\hline & Total Losses & & 582.60 \\
\hline
\end{tabular}

Sources: Individual Banks; Central Banks.

Table 2 Government Support for Global Financial Crisis 2008 USD

\begin{tabular}{l|l}
\hline Europe & $\$ 1.8$ trillion \\
\hline UK & $\$ 856$ billion \\
\hline US & $\$ 7.74$ trillion \\
\hline Sweden & \$205 billion \\
\hline South Korea & \$130 billion \\
\hline Australia & \$10.4 billion \\
\hline Rest of the world & \$105.12 billion \\
\hline Total & $\mathbf{1 0 . 9 3}$ trillion \\
\hline
\end{tabular}

Source: Compiled from

BBC Credit Crisis: World in Turmoil http://news.bbc.co.uk/2/hi/business/7654647.stm,

ABC News, Tuesday 21 of October, 2008. http://www.abc.net.au/ 
Reuters,http://www.reuters.com/article/forexNews/idUSTRE49J2GB20081020

IMF Global Financial Stability Report October 2008

http://www.imf.org/external/pubs/ft/gfsr/2008/02/index.htm

\section{Appendix 1 Transatlantic Contagion: US and European Bank Failures}

\begin{tabular}{|c|c|c|c|}
\hline 1 & $\begin{array}{l}\text { Northern } \\
\text { Rock }\end{array}$ & UK & $\begin{array}{l}\text { Northern Rock faced a run on the bank, rescued by the British government loan of } £ 26 \\
\text { billion and guarantees of } £ 30 \text { billion and effectively nationalized in February } 2008 \\
\text { ultimately extending } £ 119 \text { billion in support }\end{array}$ \\
\hline \multicolumn{4}{|c|}{ March 2008} \\
\hline 2 & Bear Sterns & US & $\begin{array}{l}\text { Federal Reserve of New York offered emergency loan, but could not be saved. Bought by } \\
\text { JPMorgan Chase in a deal sponsored by the US Federal Reserve, sold at } \$ 10 \text { per share, far } \\
\text { below } 52 \text { week highest price of } \$ 133 \text { per share. }\end{array}$ \\
\hline
\end{tabular}

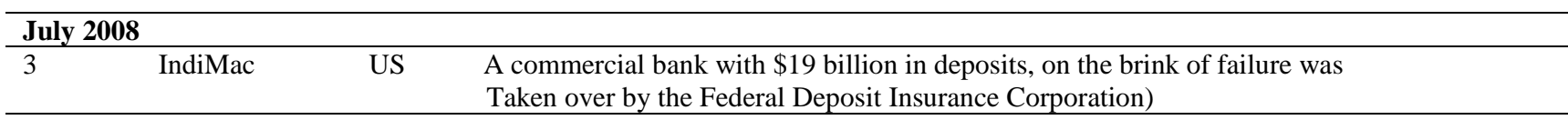

September 2008

Fannie Mae US With combined losses of $\$ 14.9$ billion and their ability to raise capital and debt

\& Freddie threatened, the two agencies had outstanding more than $\$ 5$ trillion in mortgage-backed

Mac securities (the national debt of the US is by comparison $\$ 9.5$ trillion. The US government took the two mortgage agencies into ‘conservatorship' with the Treasury contributing \$US 200 billion in preferred stock and credit through 2009

\begin{tabular}{|c|c|c|c|}
\hline 4 & AIG & US & $\begin{array}{l}\text { AIG was one of the world's largest insurance companies specializing in high margin } \\
\text { corporate coverage. It's share price fell } 95 \% \text { to } \$ 1.25 \text { from a } 52 \text { week high of } \$ 70 \text {, with } \\
\text { the company reporting a } \$ 13.2 \text { billion loss for the first six months of the year. The Federal } \\
\text { Reserve offered a credit facility of up to } \$ 85 \text { billion in exchange for warrants for a } 79.9 \% \\
\text { equity stake, the largest government bailout of a private company in US history. Later this } \\
\text { rescue package was increase to } \$ 150 \text { billion, with the US Treasury purchasing } \$ 40 \text { billion } \\
\text { in preferred shares. }\end{array}$ \\
\hline 5 & $\begin{array}{l}\text { Lehman } \\
\text { Brothers }\end{array}$ & US & $\begin{array}{l}\text { With large positions in subprime mortgages was declared bankrupt after US Federal } \\
\text { Reserve refused bailout. Barclay’s bought its investment banking arm for } \$ 1.75 \text { billion }\end{array}$ \\
\hline 6 & Merrill Lynch & US & $\begin{array}{l}\text { Bloomberg reported that Merrill Lynch had lost } \$ 51.8 \text { billion in mortgage-backed } \\
\text { securities. The firm was bought by Bank of America for } \$ \text { US } 50 \text { billion. }\end{array}$ \\
\hline 7 & HBOS & UK & The UK’s largest mortgage lender, Bought by British rival Lloyds TSB for $£ 12$ billion. \\
\hline 8 & $\begin{array}{l}\text { Washington } \\
\text { Mutual }\end{array}$ & US & $\begin{array}{l}\text { After a } 10 \text { day } \$ 16.4 \text { billion bank run was declared bankrupt and placed in the } \\
\text { receivership of the Federal Deposit Insurance Corporation; JPMorgan Chase bought the } \\
\text { banking assets from US government. Before the sixth largest bank in the US (with assets } \\
\text { of } \$ 327 \text { billion), this was the largest bank failure in US history. }\end{array}$ \\
\hline 9 & $\begin{array}{l}\text { Bradford \& } \\
\text { Bingley }\end{array}$ & UK & Nationalized by British government; Savings operations sold to Spain’s Group Santander \\
\hline 10 & Fortis & Benelux & $\begin{array}{l}\text { A banking, insurance and investment company, the } 20^{\text {th }} \text { largest business in the world by } \\
\text { revenue. Dutch operations nationalized by Netherlands; Belgian and Luxemburg } \\
\text { operations bought by France's BNP Paribas }\end{array}$ \\
\hline 11 & Dexia & Belgium & $\begin{array}{l}\text { A financial services company bailed out by French, Belgian and Luxemburg governments } \\
\text { with } € 6.4 \text { billion }\end{array}$ \\
\hline \multicolumn{4}{|c|}{ October 2008} \\
\hline 12 & Wachovia & US & $\begin{array}{l}\text { With assets of } \$ 783 \text { billion, the fourth largest bank holding company in the US. Reported } \\
\text { an anticipated } \$ 8.9 \text { billion loss for the second quarter of } 2008 \text {. Subject of a } \$ \text { US } 15 \text { billion }\end{array}$ \\
\hline
\end{tabular}




\begin{tabular}{|c|c|c|c|}
\hline 13 & Glitnir & Iceland & $\begin{array}{l}\text { One of the three major commercial banks of Iceland, Icelandic government injects } € 600 \\
\text { million for } 75 \% \text { stake, as part of a rescue of the country's entire financial system. Shortly } \\
\text { afterwards Kaupthing Edge part of Iceland's leading bank failed, and Landsbanki the } \\
\text { third bank failed, as Iceland's entire banking system collapsed and were taken over by the } \\
\text { government. Since Icelandic banks held foreign assets worth } 10 \text { times the GDP of the } \\
\text { country, there are concerns the government is bankrupt as it urgently sought loans from } \\
\text { the IMF and Russia. }\end{array}$ \\
\hline 14 & $\begin{array}{l}\text { Hypo Real } \\
\text { Estate }\end{array}$ & Germany & $\begin{array}{l}\text { The second largest commercial property lender in Germany, which includes Depfa } \\
\text { property finance bank. German government leads a } € 50 \text { billion bailout } \\
\text { with the German banks contributing } € 30 \text { billion and the Bundesbank } € 20 \text { billion }\end{array}$ \\
\hline 15 & $\begin{array}{l}\text { Preference } \\
\text { shares in: } \\
\text { Bank of } \\
\text { America, } \\
\text { Citigroup, } \\
\text { JPMorgan, } \\
\text { Wells Fargo, } \\
\text { Goldman } \\
\text { Sachs, } \\
\text { Morgan } \\
\text { Stanley, PNC, } \\
\text { and } 18 \text { other } \\
\text { banks }\end{array}$ & US & $\begin{array}{l}\text { Following a series of individual rescue attempts, the US government resolves to offer } \\
\text { general support to the failing financial system. The US Federal Treasurer Hank Poulson's } \\
\text { package of US } \$ 720 \text { billion to relieve financial institutions of subprime and other toxic } \\
\text { assets. After a troubled passage through Congress reflecting the public's anger at 'bailing } \\
\text { out Wall Street' conditions are attached regarding public oversight and executive pay. } \\
\text { Subsequently followed the UK policy in purchasing preference shares of banks to rebuild } \\
\text { the capital adequacy of large banks in the United States. }\end{array}$ \\
\hline 16 & $\begin{array}{l}\text { Preference } \\
\text { shares in: } \\
\text { Barclays, } \\
\text { HBOS, } \\
\text { Lloyds TSB, } \\
\text { Nationwide, } \\
\text { Royal Bank } \\
\text { of Scotland, } \\
\text { Abbey, } \\
\text { Standard } \\
\text { Chartered }\end{array}$ & UK & $\begin{array}{l}\text { In response to collapsing bank share prices, and a rapidly weakening financial sector, the } \\
\text { UK government determines on a major three part intervention: a } 50 \text { billion offer to buy } \\
\text { preference shares to assist the major banks to rebuild their capital reserves; £200 billion } \\
\text { of liquidity in short term loans to thaw the inter-bank lending markets; and a further £250 } \\
\text { billion to underwrite lending between banks. Conditions include restraint on dividend } \\
\text { policies, executive pay, and support for lending to small businesses and home buyers. }\end{array}$ \\
\hline 17 & UBS & Switzerland & $\begin{array}{l}\text { Swiss bank UBS AG told it expected to post net losses of } 12 \text { billion Swiss francs } \\
\text { (US } \$ 12.1 \text { billion) for the first quarter of } 2008 \text { and would seek } 15 \text { billion Swiss francs } \\
\text { (US } \$ 15.1 \text { billion) in new capital. UBS announced losses and writedowns of } \\
\text { approximately US } \$ 19 \text { billion on U.S. real estate and related credit positions, Swiss } \\
\text { government took an indirect SF } 6 \text { billion stake in UBS. Swiss national bank took \$59 } \\
\text { billion of UBS's illiquid US securities }\end{array}$ \\
\hline
\end{tabular}

\begin{tabular}{|c|c|c|c|}
\hline 18 & ING & Netherlands & $\begin{array}{l}\text { ING one of the world's largest banks with } 85 \text { million customers worldwide, and with } 385 \\
\text { billion euros in saving and current account deposits announces it expects to make a } € 500 \\
\text { third quarter loss. The Dutch government makes a } € 10 \text { billion cash injection for shares in } \\
\text { the bank. }\end{array}$ \\
\hline 19 & $\begin{array}{l}\text { D.Carnegie \& } \\
\text { Co AB }\end{array}$ & Sweden & $\begin{array}{l}\text { Sweden's largest publicly traded investment bank founded } 200 \text { years ago having lost } 87 \% \\
\text { ot its value, was seized by the Swedish government, accused of taking exceptional risks, } \\
\text { to be sold off in parts. }\end{array}$ \\
\hline 20 & Citigroup & US & $\begin{array}{l}\text { Citigroup is unable to stem losses and markets become concerned. Citigroups shares fall } \\
23 \% \text { on } 19 \text { November to their lowest since May } 1995 \text { CEO announces winding down off- } \\
\text { balance sheet businesses and making } 52,000 \text { redundancies. The following day the shares } \\
\text { fall a further } 20 \% \text {, and the day after another } 20 \% \text {. Realising only government rescue will } \\
\text { save one of the world's largest banks, the Federal Reserve and Treasury agree Citigroup a } \\
\text { "systemic risk" to allow } \$ 300 \text { billion rescue }\end{array}$ \\
\hline
\end{tabular}

